\title{
PENGOLAHAN LIMBAH AIR WUDHU WANITA DENGAN METODE AERASI DAN ADSORPSI MENGGUNAKAN KARBON AKTIF
}

\author{
Eko Prabowo Hadisantoso ${ }^{1 *}$, Yuna Widayanti ${ }^{1}$, RobBy’ATUl AdAWIYAh Hanifah ${ }^{1}$, \\ Vina Amalia ${ }^{1}$ DAN Gina Giftia A. Delilah. ${ }^{1}$ \\ ${ }^{1}$ Jurusan Kimia, Fakultas Sains dan Teknologi, UIN Sunan Gunung Djati Bandung, \\ Jl. A. H. Nasution No. 105 Cibiru Kota Bandung \\ *alamat email korespondensi: ekoph@uinsgd.ac.id
}

\begin{abstract}
Informasi Artikel Abstrak/Abstract
Riwayat Naskah :

Diterima pada 2 Mei

2018

Diterima setelah

direvisi pada 4 Juni

2018

Diterbitkan pada 28

Juni 2018

Wudhu adalah suatu rutinitas seorang muslim sebelum melaksanakan sholat. Dalam setiap kali wudhu, seorang muslim rata-rata menggunakan $3 \mathrm{~L}$ air, yang berarti $15 \mathrm{~L}$ air setiap harinya untuk wudhu. Air yang digunakan ketika wudhu hanya terkena beberapa bagian tubuh, sehingga hanya mengandung sedikit pencemar. Pada penelitian ini dilakukan pengolahan air limbah wudhu sebagai solusi penyediaan air bersih. Pengolahan dilakukan dengan menggunakan metode aerasi dan adsorpsi. Metode aerasi bertujuan menambahkan oksigen ke dalam air limbah sedangkan adsorpsi bertujuan memisahkan antara air limbah dengan partikel polutan. Pada penelitian ini tahap pertama dilakukan screening untuk mengetahui kondisi terburuk limbah. Kondisi terburuk yang diperoleh pada limbah air wudhu wanita adalah limbah waktu sholat ashar dilihat dari parameter $\mathrm{pH}$, DO, dan TSS. Tahap selanjutnya yaitu proses penanganan limbah, penanganan secara aerasi dilakukan menggunakan aerator selama 5 jam dan secara adsorpsi dilakukan menggunakan karbon aktif. Hasil analisis menunjukkan penanganan limbah air wudhu dapat meningkatkan kondisi air menjadi lebih baik dan dapat mengembalikan kondisi air ke kondisi awal (air baku). Kondisi limbah air wudhu setelah pengolahan adalah memiliki $\mathrm{pH}$ 8,40; DO 8,7 mg/L; TSS $0 \mathrm{mg} / \mathrm{L}$; COD 7,4 mg/L; BOD 5 2,3 mg/L; Minyak Lemak 7,2 mg/L; Warna 24 unit Pt-Co; Tidak

Kata Kunci: wudhu; limbah; aerasi; adsorpsi berbau; dan E. Coli < 3. Maka air hasil olahan ini masuk dalam kategori kelas IV, yaitu air untuk keperluan pertanian dan dapat dimanfaatkan untuk usaha di perkotaan, industri, dan pembangkit listrik.
\end{abstract}

Keywords: Wudhu; waste water; aeration; adsorption
Wudhu is a routine of a Muslim before doing pray. In every single wudhu, a Muslim use 5 liters a water on average, so that means a Muslim use 15 liter a water just for wudhu every day. Water is used when ablution is only affected by several parts of the body, so it only contains a small number of pollutants. In this study, the wastewater treatment was carried out as a solution for providing clean water. The treatment was carried out by aeration and adsorption method. The first step is screening to determine the worst condition of wastewater. The worst condition of wastewater obtained in female jamaah found in Ashar prayer time seen from the parameters of $\mathrm{pH}, \mathrm{DO}$, and TSS. The next step is aeration treatment was carried out using an aerator for 5 hours and adsorption using an activated carbon. The results show that the treated wastewater can improve the water condition and can restore the water to the initial condition. The condition of water after treatment is $\mathrm{pH} \mathrm{8.40;DO} 8.7 \mathrm{mg} / \mathrm{L}$; TSS 0 mg/L; COD $7.4 \mathrm{mg} / \mathrm{L} ; \mathrm{BOD}_{5} 2.3 \mathrm{mg} / \mathrm{L}$; Fat Oil $7.2 \mathrm{mg} / \mathrm{L}$; Color 24 units of Pt-Co; Odorless; and $e$. Coli <3. So the processed water is included in the category $I V$, that is water for agicultural purposes and can be used for businesses in urban, industrial, and electricity.

\section{PENDAHULUAN}

Air merupakan komponen terpenting dalam keberlangsungan hidup makhluk hidup karena merupakan kebutuhan yang tak pernah tergantikan. Namun pada keadaannya air bersih di muka bumi semakin hari semakin berkurang. Kemudian bermunculan pencemaran yang terjadi pada air bersih. Pada zaman modern ini tingkat pencemaran air semakin meningkat sebanding dengan pesatnya perkembangan industri, sehingga penggunaan air bersih di muka bumi ini menjadi tidak seimbang dan di beberapa wilayah terjadi krisis akan air bersih [1].

Peran air dalam kehidupan sehari-hari tidak hanya untuk memenuhi kebutuhan dalam aspek membersihkan diri tetapi digunakan pula pada aspek spiritual. Dalam aspek ini air digunakan dalam hal berwudhu. Bagi umat muslim berwudhu dilakukan tiap kali sebelum melakukan ibadah khususnya sholat. Berwudhu ini paling tidak dilakukan lima kali dalam satu hari atau bisa diartikan lima waktu sholat. Dalam satu kali berwudhu setiap jamaah memerlukan air bersih 
sekitar 3 L, maka dalam satu hari untuk satu jamaah berwudhu membutuhkan kurang lebih 15 L [2]. Jumlah tersebut cukup besar bila dikali jumlah umat muslim di Indonesia. Sedangkan ketersediaan air bersih di beberapa wilayah Indonesia mengalami keterbatasan.

Penggunaan air pada saat melakukan wudhu hanya untuk membasuh beberapa bagian tubuh. Pada kondisi tersebut limbah air wudhu dibuang secara langsung menuju selokan tanpa ada pemanfaatan. Sementara itu, limbah air wudhu ini termasuk air limbah gey water karena tidak tercampur dengan kotoran manusia. Limbah gey water ini dapat didaur ulang, hasil dari daur ulang tersebut dapat dimanfaatkan untuk air reklamasi yaitu menyiram tanaman, air kolam ikan, mengepel lantai atau membersihkan kendaraan [2]. Sehingga pada limbah air wudhu diperlukannya sistem pengolahan untuk memenuhi kebutuhan air bersih.

Pengolahan secara biologis dapat dilakukan sebagai alternatif pengolahan limbah gey water yang ekonomis dan sederhana. Salah satunya dengan proses aerob yang membutuhkan bantuan oksigen. Sistem pengolahan daur ulang limbah air wudhu ini berdasarkan metode aerasi dan adsorpsi. Pada pengolahan aerasi, limbah air wudhu disemprotkan udara melalui batu gelembung pada dasar limbah sehingga dapat meningkatkan kadar oksigen hingga 60-80\% dan mampu mendegadasi zat-zat organik [3]. Metode aerasi ini dipilih karena sederhana pada penerapannya sehingga mudah untuk diaplikasikan. Sedangkan pada pengolahan adsorpsi dilakukan penyerapan dengan menggunakan adsorben. Proses penyerapan ini mampu menjerap zat-zat terlarut limbah air wudhu di permukaan adsorben [4]. Pada proses adsorpsi banyak jenis adsorben yang dapat digunakan, seperti komposit, zeolit alam, atau karbon aktif. Adsorben pada metode adsorpsi ini adalah karbon aktif, karena luas penampang karbon aktif sangat luas sehingga sangat baik digunakan dalam proses adsorpsi limbah. Disamping itu, karbon aktif sendiri dapat dibuat sendiri, bilapun karbon aktif komersial mudah ditemukan di pasaran dan ekonomis.

Sistem pengolahan ini dilakukan untuk mengembalikan kondisi limbah air wudhu ke kondisi sebelum digunakan (air baku), sehingga pengolahan ini menjadi salah satu jalan keluar meminimalisir kekurangan air pada beberapa wilayah yang sulit air. Selain itu juga sistem pengolahan limbah air wudhu ini dapat menjadikan limbah air wudhu sebagai air bersih untuk keperluan reklamasi, pertanian, atau perternakan.

\section{EKSPERIMEN}

\section{Material}

Sampel air wudhu dari Pesantren AlIhsan Cibiru, karbon aktif, aqua destilasi, kertas saring whatman nomor 41, kasa steril, kapas, dan alkohol $70 \%$.

\section{Prosedur}

Sampel didapatkan dari Pesantren Al-Ihsan Cibiru Kab. Bandung. Pengambilan sampel air baku dengan cara menadahkan air kran langsung ke dalam botol sampel, sedangkan pengambilan sampel limbah air wudhu ini dengan cara menadahkan limbah air wudhu di bawah jamaah yang sedang berwudhu menggunakan wadah plastik berukuran $40 \mathrm{~L}$. Pada pengambilan sampel limbah air wudhu banyaknya jamaah berwudhu yaitu 15 orang. Secara umum pada penelitian ini terdiri dari 3 tahapan. Tahap-tahapan ini yaitu 1) screening awal, 2) analisis kondisi awal limbah, dan 3) penanganan limbah.

Pada tahap pertama yaitu screening awal, tahap ini dilakukan untuk menganalisis gambaran kondisi limbah air wudhu dan menentukan limbah air wudhu pada waktu sholat mana yang akan dilakukan pengolahan lebih lanjut. Screening ini dilakukan sebanyak 7 kali, dalam satu kali pengambilan sampel satu waktu sholat dilakukan pengujian sampel. Pengujian ini meliputi $\mathrm{pH}$, TSS, dan DO.

Pada tahap kedua yaitu analisis kondisi awal limbah, tahap ini dilakukan untuk menganalisis kondisi awal limbah dengan parameter lebih lengkap. Pengujian ini meliputi pH, TSS, DO, BOD, COD, Minyak Lemak, Warna, Bau, dan E. Coli. Hasil dari analisis ini akan menunjukkan limbah air wudhu terburuk dari lima waktu sholat. Limbah air wudhu terburuk kemudian dilakukan penanganan lebih lanjut.

Pada tahap ketiga yaitu penanganan limbah, tahap ini dilakukan berupaya kondisi sampel limbah air wudhu kembali ke kondisi sebelum digunakan (air baku). Penanganan limbah ini menggunakan metode aerasi dan adsorpsi. Aerasi dilakukan selama 5 jam, selama aerasi dilakukan pengujian $\mathrm{pH}$ dan DO tiap jam. Selanjutnya sampel hasil aerasi selama 5 jam dilakukan pengujian yaitu meliputi $\mathrm{pH}$, TSS, DO, BOD, COD, Minyak Lemak, Warna, Bau, dan E. Coli. Kemudian sampel hasil aerasi dilakukan adsorpsi menggunakan karbon aktif. Proses adsorpsi dilakukan pada penampung yang tersusun kapas dan karbon aktif, dimana tinggi kapas $5 \mathrm{~cm}$ dan tinggi karbon aktif $1,5 \mathrm{~cm}$ atau sebanyak $5 \mathrm{~g}$ 
dengan diameter penampung $6,5 \mathrm{~cm}$. Sampel hasil aerasi diadsorpsi menggunakan karbon aktif untuk memperoleh air olahan atau hasil akhir treatment. Air olahan ini dilakukan pengujian meliputi $\mathrm{pH}$, TSS, DO, BOD, COD, Minyak Lemak, Warna, Bau, dan E. Coli.

\section{HASIL DAN PEMBAHASAN}

\section{Screening Awal}

Hasil analisis pada tahap screening awal limbah air wudhu wanita ini dapat dilihat pada Gambar 1.

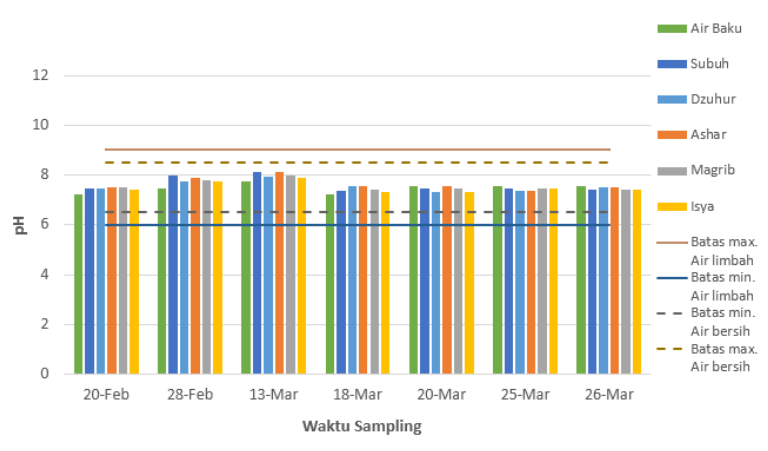

(a)

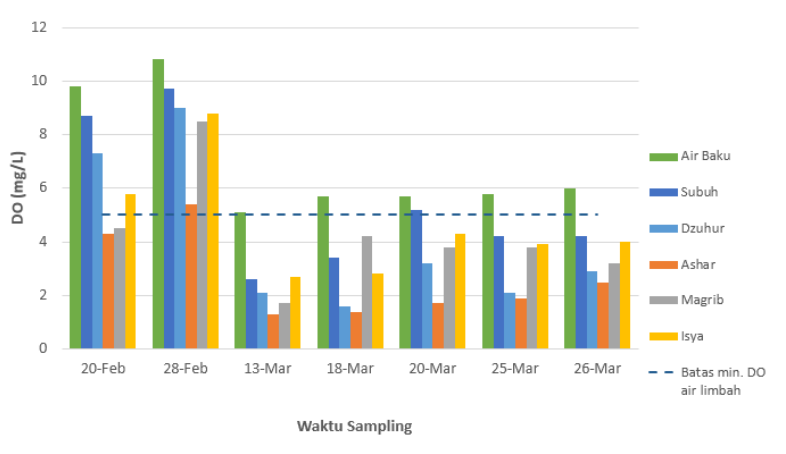

(b)

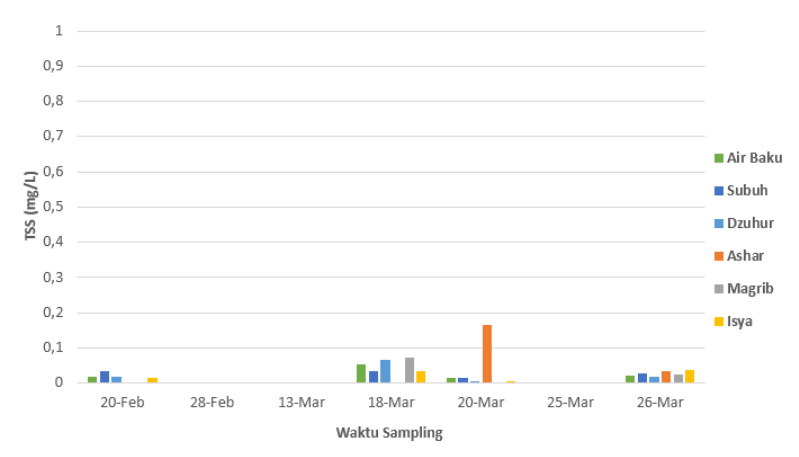

(c)

Gambar 1. Hasil analisis screening awal pada limbah air wudhu wanita pH (a); DO (b); TSS (c)
Berdasarkan hasil analisis menunjukkan pola dari limbah air wudhu wanita selama 7 kali pengambilan sampel. Pola hasil analisis $\mathrm{pH}$ pada waktu sholat dzuhur ke sholat ashar $\mathrm{pH}$ mengalami kenaikan sedangkan mengalami penurunan di sholat magib dan isya, kemudian kembali meningkat di sholat subuh. Tinggi rendahnya $\mathrm{pH}$ secara alamiah bergantung pada konsentrasi $\mathrm{CO}_{2}$ dan alkinitas dalam air. Semakin rendah konsentrasi $\mathrm{CO}_{2}$ maka semakin tinggi $\mathrm{pH}$ air. Hal ini disebabkan senyawa karbondioksida ini bersifat asam [4].

Sedangkan pola hasil analisis DO pada waktu sholat dzuhur ke sholat ashar mengalami penurunan, dan kembali meningkat dari waktu sholat ashar ke sholat magib, isya, dan subuh. Sumber utama oksigen dalam air berasal dari difusi udara melalui permukaan air. Kecepatan difusi oksigen dari udara tergantung pada beberapa faktor, salah satunya salinitas [5]. Sehingga rendahnya kadar DO pada limbah waktu sholat ashar karena terjadi peningkatan salinitas (garam). Peningkatan ini disebabkan karena pada waktu sholat ashar mayoritas santriwati dalam keadaan yang kotor setelah beraktifitas di luar pesantren. Hal ini menyebabkan pada saat berwudhu keringat tubuh terbawa oleh air wudhu, sehingga kadar DO mengalami penurunan.

Sementara itu, pola hasil analisis TSS tidak beraturan. Faktor penyebab hal ini adalah kegiatan jamaah yang berbeda-beda. Mayoritas limbah air wudhu wanita ini tidak terdapat padatan tersuspensi. Hal ini disebabkan kemampuan alat dalam analisis sehingga terjadi limit of detection. Tetapi pada waktu sholat ashar limbah air wudhu wanita ini pernah memiliki jumlah TSS terbesar dibandingkan pada waktu sholat lainnya. Hasil analisis limbah air wudhu wanita pada tahapan screening awal menunjukukkan bahwa pada waktu sholat ashar memiliki sifat terburuk.

\section{Analisis Kondisi Awal Limbah}

Hasil analisis tahapan analisis kondisi awal limbah air wudhu wanita dapat dilihat pada Tabel 1. Nilai $\mathrm{pH}$ limbah air wudhu berkisar antara 7,3 7,9. Naik turun nilai $\mathrm{pH}$ ini disebabkan konsentrasi $\mathrm{CO}_{2}$ dan alkalinitas pada limbah. Semakin tinggi konsentrasi $\mathrm{CO}_{2}$ maka nilai $\mathrm{pH}$ akan semakin rendah (lebih asam), begitu pula sebaliknya [5]. Nilai pH tinggi terdapat pada sholat subuh. Faktor lain yang menyebabkan nilai $\mathrm{pH}$ tinggi adalah aktifitas dari santriwati sendiri. Pada waktu sholat subuh mayoritas santriwati melakukan aktifitas membersihkan diri (mandi) dan juga mencuci pakaian. Sehingga nilai $\mathrm{pH}$ pada 
waktu sholat subuh tinggi karena faktor ini menyebabkan alkinitas limbah meningkat.

Data ini memperlihatkan bahwa penurunan kadar DO paling rendah terdapat pada waktu sholat isya, sedangkan penurunan kadar DO paling tinggi pada sholat ashar. Rendahnya kadar DO pada waktu sholat ashar karena terjadi peningkatan salinitas (garam), sehingga mempengaruhi kecepatan difusi oksigen dari udara. Peningkatan ini juga disebabkan karena pada waktu sholat ashar sebagian besar santriwati dalam keadaan yang kotor setelah beraktifitas di luar pesantren. Sehingga pada saat berwudhu keringat tubuh terbawa oleh air wudhu, dan menyebabkan kadar DO rendah. Tingginya kekeruhan air dan meningkatnya aktivitas mikroorganisme juga menjadi penyebab rendahnya kadar DO [6].

Tabel 1. Data Pengujian Kondisi Awal Sampel Limbah Air Wudhu Wanita

\begin{tabular}{|c|c|c|c|c|c|c|c|}
\hline \multirow{2}{*}{ Parameter (Satuan) } & \multirow{2}{*}{$\begin{array}{c}\text { Standar } \\
\text { Acuan Air } \\
\text { Limbah }\end{array}$} & \multicolumn{6}{|c|}{ Hasil Analisis } \\
\hline & & Air Baku & Subuh & Dzuhur & Ashar & Magib & Isya \\
\hline $\mathrm{pH}$ & $6-9$ & 7,5 & 7,9 & 7,35 & 7,3 & 7,4 & 7,45 \\
\hline DO (mg/L) & Min. 5 & 6,5 & 3,6 & 3,7 & 2,8 & 4,5 & 5,0 \\
\hline $\mathrm{TSS}(\mathrm{mg} / \mathrm{L})$ & Max. 30 & 0 & 0 & 0 & 165 & 0 & 0 \\
\hline COD (mg/L) & Max. 100 & 7,39 & 29,7 & 7,42 & 103,9 & 7,42 & 7,42 \\
\hline $\mathrm{BOD}_{5}\left(\mathrm{mg} / \mathrm{L} \mathrm{O}_{2}\right)$ & Max. 30 & 2,3 & 12,0 & 2,4 & 46,0 & 2,3 & 2,4 \\
\hline Minyak Lemak (mg/L) & Max. 5 & 0,12 & 30,6 & 35,1 & 42,1 & 36,5 & 34,5 \\
\hline Warna (Pt-Co) & - & 0 & 32 & 25 & 31 & 39 & 25 \\
\hline & & Tidak & Tidak & Tidak & Tidak & Tidak & Tidak \\
\hline Bau & - & Berbau & Berbau & Berbau & Berbau & Berbau & Berbau \\
\hline E. Coli (jumlah/100 mL) & Max. 3000 & $<2$ & $<3$ & $<3$ & $<3$ & $<3$ & $<3$ \\
\hline *Mengacu pada & $\begin{array}{ll}\text { raturan } \quad \mathrm{N} \\
\end{array}$ & iteri & kungan & Hidup & $\mathrm{Ke}$ & $\begin{array}{ll}\text { an } & \text { R.I }\end{array}$ & Nomor: \\
\hline
\end{tabular}

Hal ini dapat dilihat pada hasil analisis parameter TSS, BOD5, dan COD. Tingginya TSS pada limbah air wudhu sholat ashar disebabkan debu atau partikel dari tubuh jamaah terbawa saat berwudhu, karena sebagian besar santriwati baru selesai beraktifitas di luar pesantren. Selain itu juga penyebab meningkatnya TSS karena pengaruh kosmetika yang digunakan santriwati hal ini karena kosmetik yang menempel pada kulit wajah terbawa oleh air wudhu sehingga berpengaruh pada nilai TSS limbah. Kadar BOD5 pada waktu sholat ashar ini melebihi ambang batas normal. Hal ini menunjukkan bahwa limbah memiliki kandungan bahan organik yang besar, karena semakin tinggi kadar BOD5 maka semakin besar oksigen yang diperlukan mikroorganisme untuk mengurai bahan organik. Hasil analisis ini berkesinambungan dengan hasil kadar DO pada waktu sholat ashar yang rendah. Kadar COD pada waktu sholat ashar ini melebihi ambang batas normal. Seperti hal BOD5, kadar COD yang tinggi ini menunjukkan tingginya bahan organik yang terdapat pada sampel limbah air wudhu.

Kadar minyak lemak pada limbah air wudhu pada waktu sholat ashar jauh sekali bila dibandingkan dengan kadar batas normal limbah. Hal ini dapat disebabkan karena aktifitas jamaah sehari-hari di luar ruangan sehingga produksi minyak lemak pada tubuh mempengaruhi limbah air wudhu. Pengujian bau dan warna pada sampel limbah air wudhu merupakan pengujian sifat fisik dari sampel, pengujian parameter ini berdasarkan organoleptik. Pengujian ini menjadi salah satu parameter penting dalam kelayakan limbah. Dari hasil pengujian bau sampel limbah air wudhu, pada tiap waktu sholat tidak berbau. Sedangkan dari pengujian warna, pada waktu sholat magib memiliki warna paling keruh. Sementara itu, pada pengujian E. Coli limbah air wudhu masih dalam rentang normal walaupun mengalami peningkatan dari kadar E. Coli air baku.

Hasil data pengujian kondisi awal sampel limbah air wudhu wanita ini menunjukkan bahwa tingginya persentase kondisi menjadi lebih buruk terjadi pada limbah waktu sholat ashar bila dibandingkan dengan limbah waktu sholat lainnya. Hal ini juga membuktikan bahwa parameter pada pengujian screening awal sudah dapat mewakili penentuan kondisi terburuk limbah. Sehingga perlakuan penanganan limbah dilakukan terhadap sampel limbah air wudhu waktu sholat ashar.

\section{Penanganan Limbah}

Penanganan limbah ini dilakukan secara dua tahap, yaitu aerasi dan adsorpsi. Metode aerasi pada tahap penanganan limbah ini sampel limbah air wudhu diberikan penambahan oksigen dengan kapasitas oksigen pada aerator sebesar 3,5 L/menit. Penanganan limbah secara aerasi ini dilakukan selama 5 jam. Kemudian setiap jam 
aerasi dilakukan pengujian $\mathrm{pH}$ dan $\mathrm{DO}$ pada sampel limbah yang diaerasi. Metode adsorpsi ini dimana dilakukan proses pemisahan antara partikel pengotor dengan sampel hasil dari proses aerasi. Tahap ini merupakan tahap terakhir dalam pengolahan sampel limbah. Adsorben pada proses adsorpsi ini adalah karbon aktif. Hasil pengujian sampel pada limbah air wudhu sebelum dan setelah penanganan limbah pada Tabel 2 .

Tabel 2. Data Perbandingan Air Baku, Air Limbah, dan Air Hasil Penanganan (Air Olahan)

\begin{tabular}{|c|c|c|c|c|c|c|}
\hline \multirow{3}{*}{$\begin{array}{c}\text { Parameter } \\
\text { (Satuan) }\end{array}$} & \multirow{3}{*}{$\begin{array}{c}\text { Standar } \\
\text { Acuan Air } \\
\text { Bersih }(*)\end{array}$} & \multirow{3}{*}{$\begin{array}{c}\text { Standar } \\
\text { Acuan Air } \\
\text { Kelas IV } \\
(* *)\end{array}$} & \multicolumn{4}{|c|}{ Hasil Analisis } \\
\hline & & & \multirow[b]{2}{*}{ Air Baku } & \multirow[b]{2}{*}{ Air Limbah } & \multicolumn{2}{|c|}{ Air Olahan } \\
\hline & & & & & Aerasi & $\begin{array}{l}\text { Aerasi + } \\
\text { Adsorpsi }\end{array}$ \\
\hline $\mathrm{pH}$ & $6,5-8,5$ & $5-9$ & 7,5 & 7,3 & 8,45 & 8,40 \\
\hline $\mathrm{DO}(\mathrm{mg} / \mathrm{L})$ & Min. 5,0 & 0 & 6,5 & 2,8 & 8,6 & 8,7 \\
\hline TSS (mg/L) & Max. 30 & Max. 400 & 0 & 165 & 0 & 0 \\
\hline $\mathrm{COD}\left(\mathrm{mg} / \mathrm{L} \mathrm{O}_{2}\right)$ & Max. 1,5 & Max. 100 & 7,39 & 103,9 & 7,49 & 7,49 \\
\hline $\mathrm{BOD}_{5}\left(\mathrm{mg} / \mathrm{L} \mathrm{O}_{2}\right)$ & Max. 1,0 & Max. 12 & 2,3 & 46,0 & 2,3 & 2,3 \\
\hline $\begin{array}{c}\text { Minyak Lemak } \\
(\mathrm{mg} / \mathrm{L})\end{array}$ & Max. 5,0 & - & 0,12 & 42,1 & 4,2 & 7,20 \\
\hline Warna (Pt-Co) & Max. 50 & - & 0 & 31 & 18 & 24 \\
\hline & & & Tidak & Tidak & Tidak & Tidak \\
\hline Bau & - & - & Berbau & Berbau & Berbau & Berbau \\
\hline E. Coli & Max. 50 & Max. 2000 & $<2$ & $<3$ & $<3$ & $<3$ \\
\hline
\end{tabular}

(*)Pemenkes Nomor: 32 Tahun 2017 Tentang Baku Mutu Kesehatan Lingkungan untuk Media Air untuk Keperluan Higienis Sanitasi

(**)Peraturan Pemerintah Nomor: 82 Tahun 2001 Tentang Pengelolaan Kualitas Air Dan Pengendalian Pencemaran Air

Pada Tabel 2 menujukkan terjadi perubahan $\mathrm{pH}$ sampel menjadi sedikit basa setelah diaerasi. Hal ini disebabkan karena pada proses aerasi menyebabkan $\mathrm{CO}_{2}$ terlarut menjadi $\mathrm{CO}_{2}$ gas meninggalkan air [7]. Sementara itu, pH dari sampel hasil adsorpsi tidak menunjukkan perubahan besar dari hasil $\mathrm{pH}$ sampel hasil aerasi. Hasil pengujian $\mathrm{pH}$ sampel hasil adsorpsi hanya sedikit lebih asam dari sampel hasil aerasi.

Pada Tabel 2 juga menunjukkan terjadi peningkatan kadar DO sampel. Hal ini disebabkan terjadinya proses transfer gas secara difusi antara udara dan air sehingga menyebabkan kandungan oksigen terlarut dalam sampel meningkat. Semakin lamanya waktu aerasi maka kandungan oksigen terlarut semakin meningkat [7]. Sementara itu, DO dari sampel hasil adsorpsi tidak menunjukkan perubahan besar dari sampel hasil aerasi.

Pengujian TSS pada sampel limbah setelah diaerasi menunjukkan tidak ada padatan tersuspensi. Bila dilihat pada kondisi awal sampel memiliki kandungan padatan tersuspensi. Penurunan TSS ini disebabkan karena pada saat aerasi terjadinya penambahkan konsentrasi oksigen ke dalam sampel limbah, maka hal ini dapat menghancurkan padatan yang tergumpal. Sehingga mempermudah penyerapan oksigen dan bakteri-bakteri aerob yang berfungsi sebagai pengurai dapat bertumbuh dengan baik dan semakin banyak bakteri pengurai yang dapat mengurai padatan yang tergumpal sehingga nilai TSS menjadi turun [8].

Pengujian COD pada sampel limbah air wudhu setelah diaerasi ini menujukkan penurunan kadar COD. Penurunan kadar COD terjadi karena terjadinya penambahan asupan oksigen ke dalam sampel limbah sehingga terjadi proses oksidasi oleh mikroorganisme yang menyebabkan penurunan senyawa organik pada sampel limbah. Sementara itu, sama seperti halnya pada pengujian $\mathrm{BOD}_{5}$ terjadi penurunan yang cukup besar. Hal ini disebabkan terjadinya asupan oksigen ke air limbah mengakibatkan meningkatnya laju penguraian yang diakibatkan oleh bertumbuhnya populasi organisme yang baik [8].

Pengujian minyak lemak pada sampel limbah air wudhu juga mengalami penurunan yang cukup besar. Walaupun demikian kadar minyak lemak masih terhitung cukup besar karena hampir melebihi ambang batas normal. Hal ini disebabkan pemberian oksigen pada limbah air wudhu dapat memisahkan minyak dengan air yang belum dapat terpisah. Terpisahnya minyak dari air maka minyak akan terflotasi ke atas akibat massa jenis air lebih kecil dari massa jenis air [8].

Pengujian bau sampel limbah yaitu tidak berbau. Sedangkan dari pengujian warna hasil sampel limbah diaerasi lebih jernih dari kondisi awal, tetapi pada sampel hasil adsorpsi mengalami peningkatan. Hal ini disebabkan karena karbon aktif dalam proses adsorpsi ini kurang bersih ketika dicuci. Sehingga sampel hasil adsorpsi ini 
mengalami peningkatan unit Pt-Co. Sementara pada pengujian E. Coli tidak terjadi perubahan pada limbah air wudhu dengan hasil aerasi dan hasil adsorpsi. Kadar E. Coli masih dalam rentang normal Dari hasil pengujian ini menunjukkan bahwa pada tahapan ini masih belum bisa mengatasi penurunan kadar E. Coli pada limbah.

Kondisi akhir air olahan dibandingkan dengan air baku maka pada parameter minyak lemak dan warna masih membutuhkan penanganan lebih lanjut. Sedangkan bila dibandingkan dengan standar acuan baku mutu untuk air keperluan higienis sanitasi maka pada parameter COD, BOD, dan minyak lemak masih membutuhkan penanganan lebih lanjut sehingga mencapai baku mutu. Sejauh ini kondisi limbah air wudhu ini kembali menjadi kondisi semula (air baku). Air olahan tersebut ini juga masuk pada kategori air kelas IV yaitu air untuk keperluan pertanian dan dapat dimanfaatkan untuk usaha di perkotaan, industri, dan pembangkit listrik tenaga air.

\section{SIMPULAN}

Dari hasil penelitian ini dapat ditarik kesimpulan sebagai berikut; Kondisi limbah air wudhu mengalami penurunan kualitas air yang signifikan dibandingkan dengan kondisi air baku, Kondisi terburuk sampel limbah air wudhu wanita terjadi di waktu sholat ashar, dan Kondisi sampel limbah air wudhu dapat kembali ke kondisi semula (air baku) setelah dilakukan pengolahan limbah air wudhu dengan metode aerasi yang dilanjutkan adsorpsi menggunakan karbon aktif. Air hasil pengolahan tergolong sebagai air kelas IV berdasarkan PP 82/2001.

\section{UCAPAN TERIMA KASIH}

Ucapan terima kasih disampaikan kepada LP2M UIN Sunan Gunung Djati Bandung atas dukungan pembiayaan penelitian Tahun Anggaran 2018.

\section{REFERENSI}

[1] World Health Organization (WHO) and the United Nations Children's Fund (UNICEF), "Progess on Drinking Water, Sanitation and Hygiene 2017 Update and SDG Baselines," Denmark, 2017.
[2] Bahagia and Muhamad Nizar, "Analisis Pengelolaan Air Bekas Wudhu Jamaah Mesjid Jamik Lambaro Kabupaten Aceh Besar," Serambi Engineering, vol. III, pp. 209-214, Januari 2018.

[3] Suprihatin Luluk Edahwati , "Kombinasi Proses Aerasi, Adsorpsi, dan Filtrasi Pada Pengolahan Air Limbah Industri Perikanan," Ilmiah Teknik Lingkungan, vol. 1.

[4] J. B. F Sihombing, Penggunaan Media Filtran Dalam Upaya Mengurangi Beban Cemaran Limbah Cair Industri Kecil Tapioka. Bogor: Departemen Teknologi Industri Pertanian Fakultas Teknologi Pertanian Institut Pertanian, 2007.

[5] Alfrida E Suoth and Ernawati Nazir, "Karakteristik Air Limbah Rumah Tangga (Gey Water) Pada Salah Satu Perumahan Menengah Keatas Yang Berada Di Tangerang Selatan," Ecolab, vol. X, pp. 8088, Juli 2016.

[6] Simon I Patty, "Oksigen Terlarut Dan Apparent Oxygen Utilization Di Perairan Selat Lembeh Sulawesi Utara," Jurnal Ilmiah Platax, vol. VI, no. 1, pp. 54-60, Januari 2018.

[7] Kapri Batara, Badrus Zaman, and Wiharyanto Oktiawan, "Pengaruh Debit Udara dan Waktu Aerasi Terhadap Efisiensi Penurunan Besi Dan Mangan Menggunakan Diffuser Aerator Pada Air Tanah," Jurnal Teknik Lingkungan, vol. VI, pp. 1-10, 2017.

[8] Made Arsawan, I Wayan Budiarsa Suyasa, and Wayan Suarna, "Pemanfaatan Metode Aerasi Dalam Pengolahan Limbah Berminyak," Ecotrophic, vol. II, no. 2, pp. 19, November 2007.

[9] Paul Bormans, Ceramics are more than Clay Alone. Cambridge: Cambridge International Science Publishing, 2004.

[10] M. P. Fewell, "The atomic nuclide with the highest mean binding energy," American Journal of Physics, vol. 63, no. 7, pp. 653658, 1995. 